\title{
Petrography and Geochemistry of the Banded Iron Formation of the Gangfelum Area, Northeastern Nigeria
}

\author{
Anthony Temidayo Bolarinwa ${ }^{1}$ \\ ${ }^{1}$ Department of Geology, University of Ibadan, Ibadan, Nigeria \\ Correspondence: Anthony Temidayo Bolarinwa, Department of Geology, University of Ibadan, Ibadan, Nigeria. \\ E-mail: atbola@yahoo.com
}

Received: September 15, 2016

Accepted: October 3, $2016 \quad$ Online Published: October 3, 2017

doi:10.5539/esr.v7n1p25

URL: https://doi.org/10.5539/esr.v7n1p25

\begin{abstract}
The Gangfelum Banded Iron Formation (BIF) is located within the basement complex of northeastern Nigeria. It is characterized by alternate bands of iron oxide and quartz. Petrographic studies show that the BIF consist mainly of hematite, goethite subordinate magnetite and accessory minerals including rutile, apatite, tourmaline and zircon. Chemical data from inductively coupled plasma optical emission spectrometer (ICP-OES) and inductively coupled plasma mass spectrometer (ICP-MS) show that average $\mathrm{Fe}_{2} \mathrm{O}_{3(\mathrm{t})}$ is $53.91 \mathrm{wt} . \%$. The average values of $\mathrm{Al}_{2} \mathrm{O}_{3}$ and $\mathrm{CaO}$ are 1.41 and 0.05 wt.\% respectively, $\mathrm{TiO}_{2}$ and $\mathrm{MnO}$ are less than $0.5 \mathrm{wt} . \%$ each. The data suggested that the $\mathrm{BIF}$ is the oxide facies type. Trace element concentrations of $\mathrm{Ba}$ (67-332 ppm), Ni (28-35 ppm), Sr (13-55 ppm) and $\mathrm{Zr}(16-25 \mathrm{ppm})$ in the Gangfelum BIF are low and similar to the Maru and Muro BIF in northern Nigeria and also the Algoma iron formation from North America, the Orissa iron oxide facies of India and the Itabirite from Minas Gerais in Brazil. The evolution of the Gangfelum BIF involved metamorphism of chemically precipitated or rhythmically deposited iron-rich sediments into hematite-quartz rocks. The banding of the BIF suggested a break in iron precipitation probably due to iron oxide deficiency.
\end{abstract}

Keywords: Banded Iron Formation, geochemistry, hematite, goethite, Gangfelum

\section{Introduction}

The Banded Iron Formations (BIFs) occur within the Precambrian basement complex of Nigeria around the Lokoja-Okene-Kabba, Maru, Muro and Birnin Gwari schist belts (Figure 1). These rocks are commonly associated with the metasedimentary and metavolcanic rocks of Late Proterozoic age. Three main facies of the BIFs in Nigeria are recognised, which include the oxide, silicate and sulphide facies. The oxide facies, represented by the banded silica-iron oxide assemblage, is the most widespread in occurrence. The silicate facies consists of the quartz-garnetgrunerite assemblage, while the sulphide facies includes the pyrite-bearing carbonaceous schist or phyllite intercalated with iron-rich layers.

Olade (1978) classified the Itakpe ore deposit around Okene (Figure 1) into a massive magnetite, a banded to granular hematite-magnetite, and a homogenous hematite-magnetite ores. This ore deposit is regarded as a product of high grade amphibolite facies metamorphism of iron-rich sediments (Olade, 1978). Mucke \& Neumann (1986) reported dark iron-rich bands alternating with lighter quartz bands in the rocks of the Ajabonoko area (Figure 1). A total thickness of $200 \mathrm{~m}$ and a conservative reserve of 60 million tonnes were estimated for this ore deposit. Adekoya (1998) and Adekoya et al. (2012) reported the occurrence of BIF within the pelitic to semi-pelitic phyllites of the Maru and Muro areas. The $\mathrm{Fe}_{2} \mathrm{O}_{3(t)}$ of the deposit is said to range from 44.07 to 58.41 wt.\%. Okonkwo (1980) noted the occurrence of a BIF in the phyllite and quartz mica-schist of the Kushaka schist belt (Figure 1). Others include the magnetite-rich Kakun ore deposit, reported to be of igneous progenitor (Mucke \& Neumann, 1986), and the Agbado-Okudu and Ochokochoko hematitic ore deposits in southwestern Nigeria. However, very little is known about the Gangfelum iron deposit due to poor accessibility. This work was carried out to investigate the petrography, geochemistry and origin of the iron ore mineralization in the Gangfelum District, Adamawa area, northeastern Nigeria.

\section{Geological Setting}

The Gangfelum area lies between the longitude $11^{\circ} 55^{\prime} \mathrm{E}$ and $12^{\circ} 00^{\prime} \mathrm{E}$ and the latitude $8^{\circ} 49^{\prime} \mathrm{N}$ and $8^{\circ} 55^{\prime} \mathrm{N}$ (Figure 1). The area is generally undulating with a high relief of about $1400 \mathrm{~m}$ and lowland area of $408 \mathrm{~m}$ to $447 \mathrm{~m}$. It is 
part of the Mambila Plateau which stretches to the northwestern parts of Cameroun (Figure 1). The Adamawa, Hawal and Oban Massifs form the eastern sector of the Nigerian Basement Complex. Within this sector, only the Oban Massif has been studied in detail (Haruna et al., 2011, 2013). The Adamawa and Hawal Massifs form the continental sector of major volcanic centers, which extends over $1000 \mathrm{~km}$ from the South Atlantic to Central Cameroun (Fitton, 1980). Adamawa massif is within the Pan-African Province of West Africa whose diverse basement rocks are affected by episodes of orogenies that resulted in the intense deformation, igneous activity, folding, metamorphism, melting, uplift and widespread fracturing of the rocks.

Migmatite covers more than one-third of the study area extending in the northeast-southwest direction. Prominent migmatite ridges occur around Wuro, Gboki and Zabi (Figure 2). Biotite-hornblende gneiss occurs in the southwestern part of the study area (Figure 2). Porphyritic granite occurs at the north and northeastern parts of the area (Figure 2). They are medium to coarse grained. Foliation in the rock is defined by the parallel alignment of feldspar megacryst and biotite specks. The iron oxide-rich veins trend SW-NE in the Gangfelum, Sakla and Dadoru villages (Figure 2). The veins are about $2.4 \mathrm{~m}$ long, $0.5 \mathrm{~m}$ wide and $1 \mathrm{~m}$ thick.

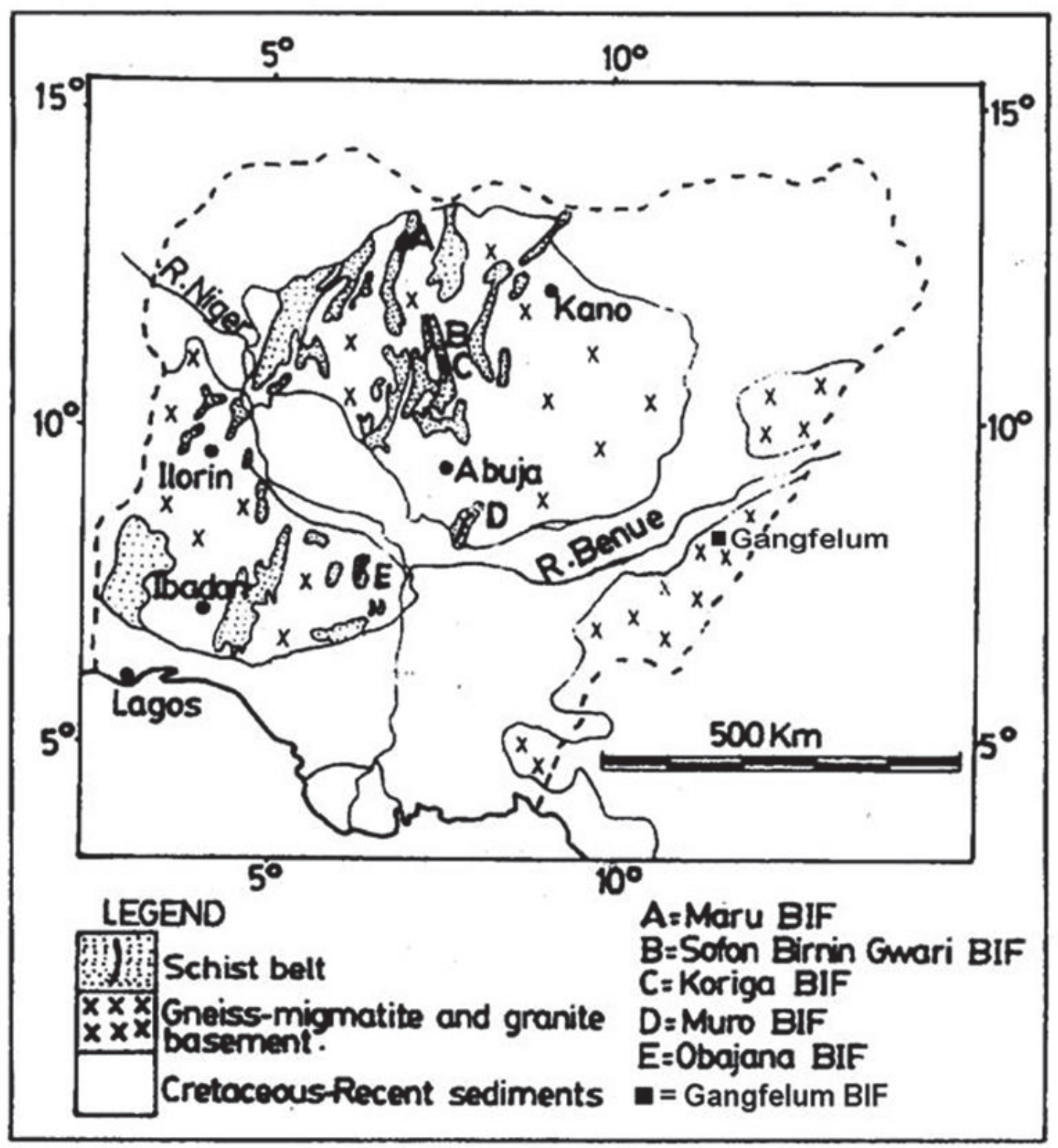

Figure 1. Geological map of Nigeria (Oyawoye, 1970) showing the location of Gangfelum BIF and other BIFs in Nigeria 


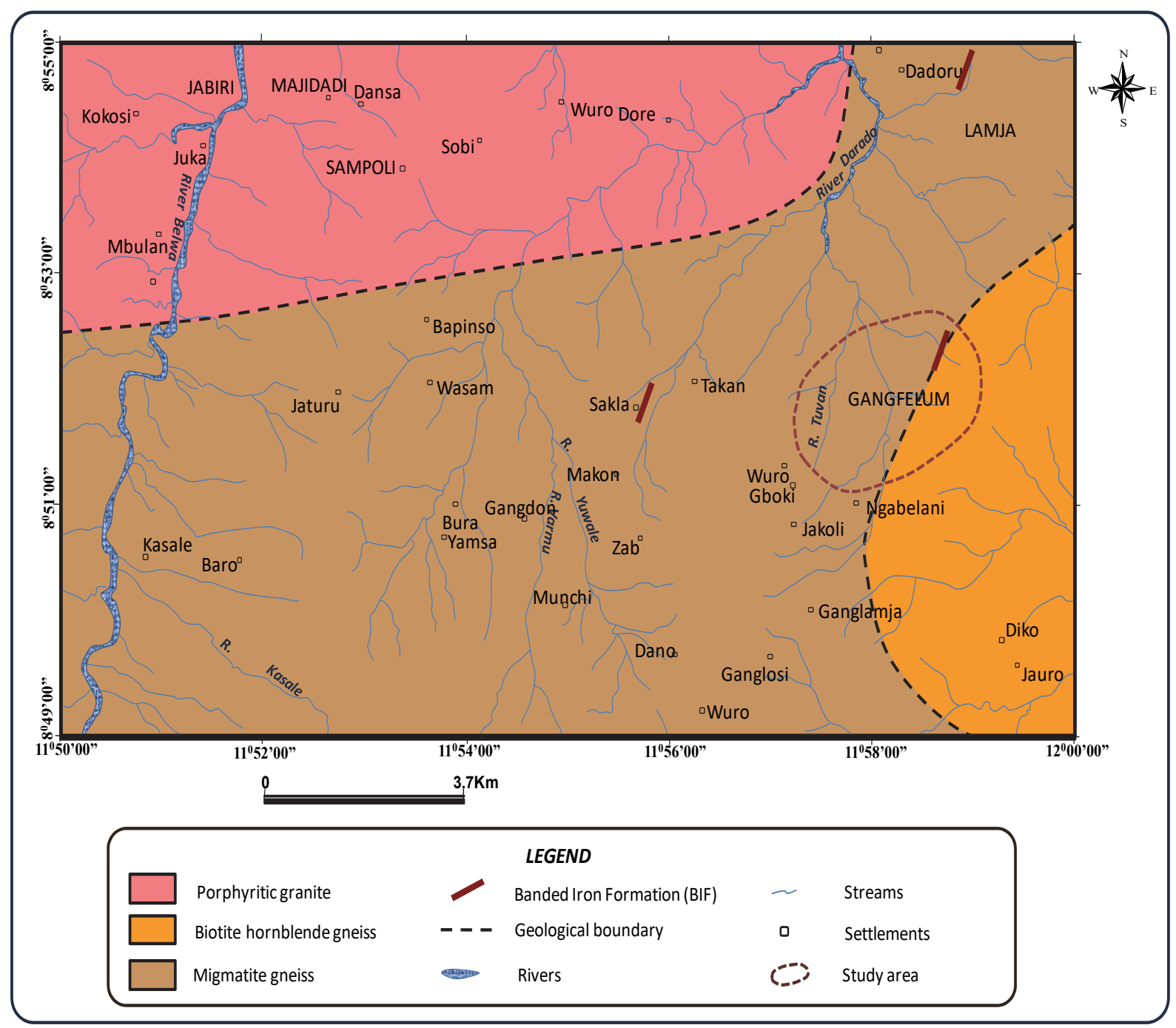

Figure 2. Geological map of the Gangfelum area

\section{Method}

The polished thick sections of the BIF ore samples prepared in the Department of Geology, University of Ibadan, Ibadan, Nigeria were examined under a reflected light ore microscope. Five representative iron ore samples were pulverized and analysed at the ACME Analytical Laboratories, Canada for X-ray diffraction analysis. The X-ray

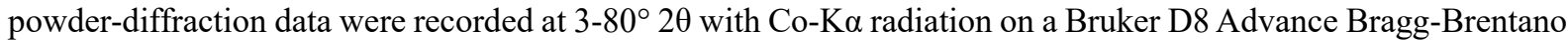
diffractometer equipped with a Lynx Eye-XE detector. The X-ray tube was operated at $35 \mathrm{kV}$ and $40 \mathrm{~mA}$. The Xray diffractogram was analyzed using the International Centre for Diffraction Database PDF-4 and Search-Match software by Bruker. The diffraction data was refined with Rietveld program Topas 4.2 (Bruker AXS), and interpreted using diagnostic patterns of standard minerals in the JCPDS (1974) diffraction file.

Twenty one representative samples of the iron ore were pulverized and analyzed using the inductively coupled plasma optical emission spectrometer (ICP-OES) and inductively coupled plasma mass spectrometer (ICP-MS) methods following a lithium metaborate/tetraborate fusion and nitric acid digestion of a $0.2 \mathrm{~g}$ sample at the ACME Laboratory in Vancouver, Canada. Major and trace elements contents of the iron ore samples were determined. The detection limit is $>0.01 \%$ for the major elements, and $>0.5 \mathrm{ppm}$ for the trace elements. Many international standards were used for the measurement of accuracy and precision of analyses. These standards were analysed alongside the BIF samples as unknowns. Duplicate samples were also analysed. The resulting precision was better than $5 \%$ for most of the elements. 


\section{Results and Discussion}

\subsection{Petrography and Mineralogy}

The Gangfelum BIF is hard and compact, fine-grained, reddish-brown to black in colour. It is banded consisting of thin alternating iron-rich and silica-rich layers. The thin $(\mathrm{mm})$ iron-rich layers containing hematite, goethite and magnetite alternating with thicker $(\mathrm{cm})$ quartz-rich layers were observed in the hand specimen. Photomicrographs of the BIF samples are shown in Figure 3. Quartz, hematite, goethite, magnetite and some accessory minerals, notably rutile, apatite, tourmaline and zircon were identified in the polished section of the ore. The light coloured minerals are magnetite and hematite while the darker grains are quartz replaced with goethite. Quartz crystals occur as interlocking mosaic in transmitted light. Fractures in the quartz crystals indicate the effect of postdeformational stress Also, crystals of quartz, albite, amphibole and other silicate grains occur as inclusions within hematite and magnetite. Ilmenite and maghemite occur as gold-coloured minute inclusions.

The X-ray diffraction analysis on five representative samples showed that hematite constitutes about $42 \mathrm{vol} . \%$ of the ore (Figure 4). Hematite $\left(\alpha-\mathrm{Fe}_{2} \mathrm{O}_{3}\right)$ peaks occur at $2 \theta$ degrees of 24.25, 33.30, 35.27, 41.02 and 54.20. Goethite $\left[\alpha-\mathrm{Fe}^{3+} \mathrm{O}(\mathrm{OH})\right]$ peaks occur at $2 \theta$ degrees of $22.25-21.41$ and 41.22 . Quartz content is about $41 \mathrm{vol} . \%$ of the ore. The presence of $\alpha-\mathrm{Fe}_{2} \mathrm{O}_{3}, \alpha-\mathrm{Fe}^{3+} \mathrm{O}(\mathrm{OH})$ and $\alpha$-quartz portends metasedimentary origin. Magnetite peaks are reflected at 30.1, 35.50, and $43.102 \theta$ degrees, while ilmenite and maghemite peaks are very weak (Figure 4).
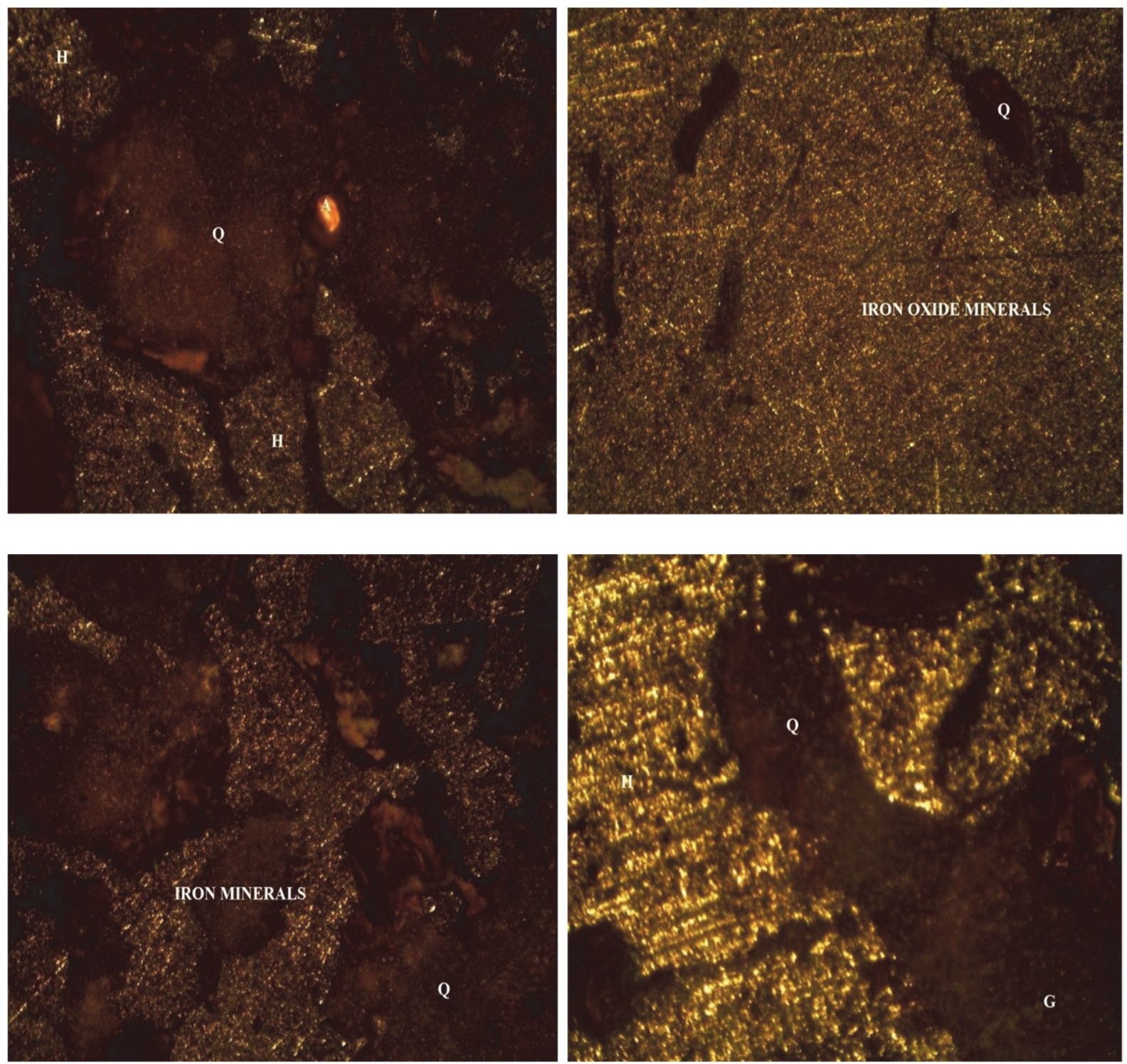

Figure 3. Photomicrograph of the Gangfelum iron ore. Reflected light microscope (x 10)

Top - Quartz (Q) impregnated with goethite (reddish-brown) and hematite (H). Bottom - Quartz (Q) impregnated 
with goethite (reddish-brown) and goethite $(\mathrm{G})$ with subhedral hematite and magnetite grains $(\mathrm{H})$.

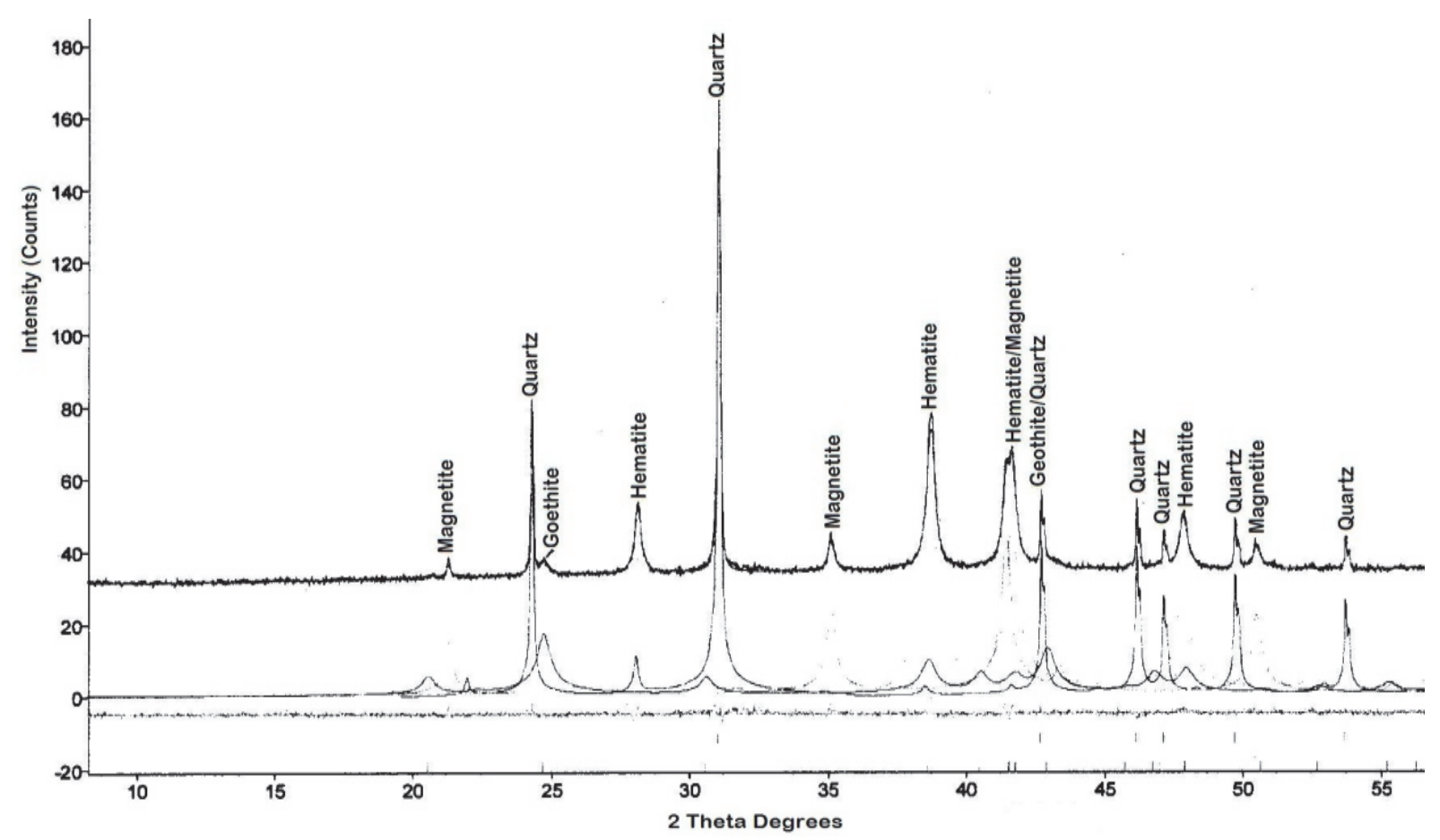

Figure 4. X-ray diffraction chart of the BIF sample from Gangfelum area

\subsection{Geochemistry}

Results of the chemical compositions of the twenty-one samples of the Gangfelum BIF were grouped into seven, based on petrography and chemical similarities and presented in Table 1. As shown in Table 1, the $\mathrm{Fe}_{2} \mathrm{O}_{3(t)}$ content ranged from 47.8-61.77 wt.\% with an average value of 53.91 wt.\%. The high $\mathrm{Fe}_{2} \mathrm{O}_{3(\mathrm{t})}$ value may be attributed to supergene enrichment due to impregnations and replacements associated with post-metamorphic activities. The pre-metamorphic kaolinite precursor are impregnated with and partially replaced by hematite and goethite in the

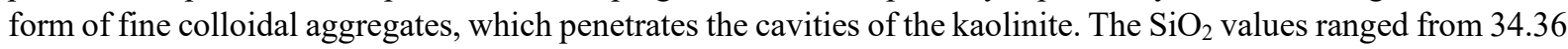
$-48.26 \mathrm{wt}$. \% with an average value of $41.98 \mathrm{wt}$. \%. The silica content is inversely proportional to the iron content. Alumina has an average value of $1.41 \mathrm{wt}$. \% and ranged between $0.98-2.30 \mathrm{wt}$. \%. The $\mathrm{CaO}$ content of the iron ore is very low with an average value of 0.05 wt. \%. Other oxides such as $\mathrm{TiO}_{2}$ and $\mathrm{MnO}$ are less than $0.5 \mathrm{wt} . \%$ each, while $\mathrm{P}_{2} \mathrm{O}_{5}$ is less than 0.01 . The chemical data suggested that the BIF is the oxide facies type. Trace element concentrations; $\mathrm{Ba}$ (67-332 ppm), Ni (28-35 ppm), Sr (13-55 ppm) and $\mathrm{Zr}(16-25 \mathrm{ppm})$; in the Gangfelum BIF are low but similar to other Precambrian iron ores all over the world.

The variation diagrams of the chemical data showed that $\mathrm{Fe}_{2} \mathrm{O}_{3(\mathrm{t})}$ increases with a decrease in silica and $\mathrm{Al}_{2} \mathrm{O}_{3}$, which possibly indicates replacement of precursor silica and kaolinite with goethite, which subsequently dehydrated to hematite. This is similar to the observation of Mucke \& Neumann (1986) on the BIF of Itakpe area, Nigeria. $\mathrm{Al}_{2} \mathrm{O}_{3}$ decreases with increase in $\mathrm{TiO}_{2}$ indicating a similar genetic source for the $\mathrm{TiO}_{2}$ and $\mathrm{Fe}_{2} \mathrm{O}_{3(\mathrm{t})}$ in the BIF samples. The plot of $\mathrm{CaO}+\mathrm{MgO}$ against $\mathrm{Na}_{2} \mathrm{O}+\mathrm{K}_{2} \mathrm{O}$ showed a weak positive correlation (Figure 5) suggesting low contamination during precipitation of the BIF. The Gangfelum BIF also plots within the field of the Precambrian BIF as shown on the Govett (1966) $\mathrm{Al}_{2} \mathrm{O}_{3}-\mathrm{SiO}_{2}-\mathrm{Fe}_{2} \mathrm{O}_{3}$ ternary diagram (Figure 6).

The Gangfelum BIF is similar to the Maru and Muro BIFs in Nigeria (Table 2). The Kakun iron ore, within the same Precambrian basement complex of Nigeria, has lower silica and higher magnetite contents and has been postulated to be associated with igneous and meta-igneous precursor due to the presence of exolution blebs of ilmenite in bornite, high magnetite contents and some peculiar trace and rare-earths compositions (Okolo, 1987). The average $\mathrm{Fe}_{2} \mathrm{O}_{3(\mathrm{t})}, \mathrm{Al}_{2} \mathrm{O}_{3}, \mathrm{TiO}_{2}, \mathrm{MgO}, \mathrm{CaO}, \mathrm{Na}_{2} \mathrm{O}, \mathrm{Cr}$, Ni and $\mathrm{Zn}$ content of the Kakun ore is higher compared to the Maru and Muro BIF. Abhulimen (1986) stated that the occurrence of the Kakun iron ore in form of plugs or dykes suggested magmatic origin. Hematite is the major iron oxide present in the Gangfelum iron ore with subordinate magnetite and goethite, unlike the Maru, Muro and Kakun ones which have magnetite as their major 
iron oxide with specular hematite in the Muro, Maru and Birnin Gwari ores. The Kakun ores, on the other hand, have no hematite as reported by Okolo (1987).

Table 1. Major (wt.\%) and Trace elements (ppm) composition of the iron ore samples in the Gangfelum area

\begin{tabular}{lccccccccc}
\hline Oxides & $\mathbf{1}$ & $\mathbf{2}$ & $\mathbf{3}$ & $\mathbf{4}$ & $\mathbf{5}$ & $\mathbf{6}$ & $\mathbf{7}$ & Average & Range \\
\hline & $\mathbf{n = 3}$ & $\mathbf{n = 3}$ & $\mathbf{n = 3}$ & $\mathbf{n = 3}$ & $\mathbf{n = 3}$ & $\mathbf{n = 3}$ & $\mathbf{n}=\mathbf{3}$ & $\mathbf{n = 2 1}$ & $\mathbf{n = 2 1}$ \\
\hline $\mathrm{SiO}_{2}$ & 46.29 & 48.26 & 47.28 & 34.36 & 38.52 & 39.91 & 39.23 & 41.98 & $34.36-48.26$ \\
$\mathrm{TiO}_{2}$ & 0.35 & 0.29 & 0.32 & 0.44 & 0.40 & 0.38 & 0.39 & 0.37 & $0.29-0.44$ \\
$\mathrm{Al}_{2} \mathrm{O}_{3}$ & 2.30 & 1.42 & 1.86 & 0.98 & 1.66 & 0.56 & 1.11 & 1.41 & $0.98-2.30$ \\
$\mathrm{Fe}_{2} \mathrm{O}_{3(\mathrm{t})}$ & 47.86 & 48.22 & 48.04 & 61.77 & 56.72 & 57.59 & 57.16 & 53.91 & $47.86-61.77$ \\
$\mathrm{MnO}$ & 0.09 & 0.08 & 0.09 & 0.10 & 0.10 & 0.09 & 0.10 & 0.09 & $0.08-0.10$ \\
$\mathrm{MgO}$ & 0.03 & 0.01 & 0.02 & 0.02 & 0.02 & $<0.01$ & 0.01 & 0.02 & $<0.01-0.03$ \\
$\mathrm{CaO}$ & 0.06 & 0.04 & 0.05 & 0.06 & 0.05 & 0.05 & 0.05 & 0.05 & $0.04-0.06$ \\
$\mathrm{Na} \mathrm{O}_{2} \mathrm{O}$ & 0.32 & 0.19 & 0.26 & 0.1 & 0.21 & 0.05 & 0.13 & 0.18 & $0.05-0.32$ \\
$\mathrm{~K} 2$ & 0.80 & 0.47 & 0.64 & 0.22 & 0.51 & 0.10 & 0.31 & 0.44 & $0.10-0.80$ \\
$\mathrm{LOI}$ & 1.80 & 0.90 & 1.35 & 1.90 & 1.70 & 1.20 & 1.45 & 1.47 & $0.90-1.90$ \\
\hline $\mathbf{T o t a l}$ & $\mathbf{9 9 . 9}$ & $\mathbf{9 9 . 8 8}$ & $\mathbf{9 9 . 9 1}$ & $\mathbf{9 9 . 9 5}$ & $\mathbf{9 9 . 8 9}$ & $\mathbf{9 9 . 9 3}$ & $\mathbf{9 9 . 9 4}$ & $\mathbf{9 9 . 9 2}$ & $\mathbf{9 9 . 8 8 - 9 9 . 9 5}$ \\
\hline $\mathbf{T r a c e}$ elements (ppm) & & & & & & & & \\
$\mathrm{Ba}$ & 332 & 209 & 271 & 125 & 231 & 67 & 149 & 198 & $67-332$ \\
$\mathrm{Co}$ & 22 & 28 & 25 & 30 & 28 & 45 & 38 & 31 & $22-45$ \\
$\mathrm{Cr}$ & 41 & 45 & 42 & 48 & 41 & 60 & 46 & 46 & $41-60$ \\
$\mathrm{Cu}$ & 10 & 13 & 14 & 16 & 12 & 25 & 15 & 15 & $10-25$ \\
$\mathrm{Ni}$ & 28 & 30 & 29 & 29 & 29 & 35 & 32 & 30 & $28-35$ \\
$\mathrm{Sr}$ & 55 & 37 & 46 & 38 & 38 & 13 & 26 & 36 & $13-55$ \\
$\mathrm{Zn}$ & 11 & 15 & 12 & 10 & 14 & 10 & 12 & 12 & $10-15$ \\
$\mathrm{Zr}$ & 25 & 17 & 21 & 20 & 20 & 16 & 18 & 20 & $16-25$ \\
$\mathrm{Y}$ & 8 & 5 & 7 & 8 & 8 & 6 & 7 & 7 & $5-8$ \\
$\mathrm{Nb}$ & 15 & 11 & 13 & 19 & 19 & 16 & 18 & 16 & $11-19$ \\
$\mathrm{Sc}$ & 4 & 3 & 4 & 4 & 4 & 3 & 4 & 4 & $3-4$ \\
\hline
\end{tabular}

$\mathrm{n}=21-$ Number of samples
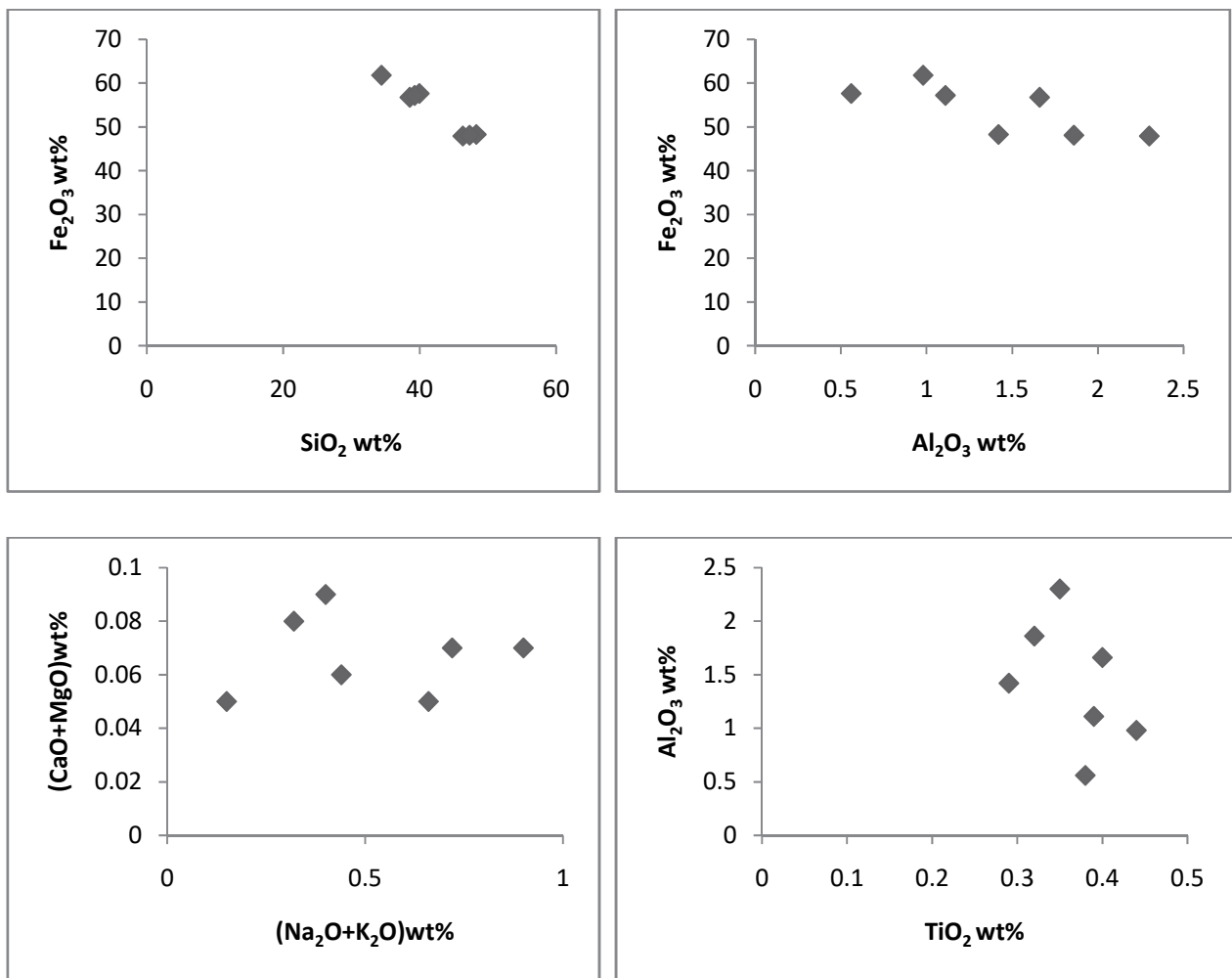

Figure 5. Binary plots of major oxides of the Gangfelum iron ore 


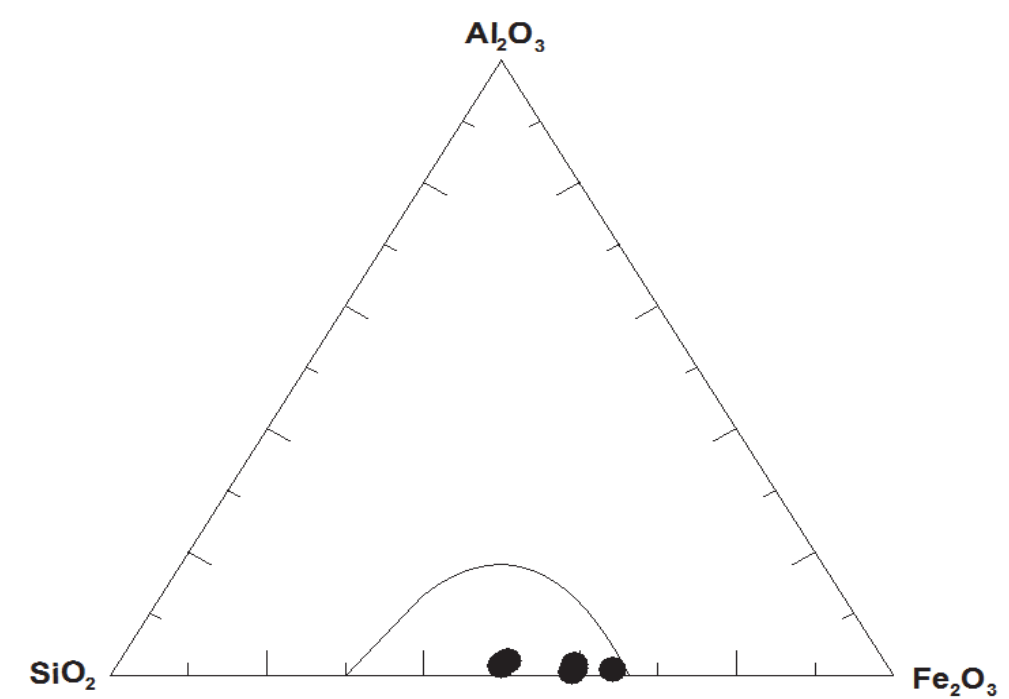

Figure 6. Plot of the Gangfelum iron formation in the Precambrian field of $\mathrm{SiO}_{2}-\mathrm{Al}_{2} \mathrm{O}_{3}-\mathrm{Fe}_{2} \mathrm{O}_{3}$ ternary diagram (after Govett, 1966)

Table 2. Averages and ranges of major oxide (wt.\%) and trace elements (ppm) of iron-formations from Gangfelum, Maru, Muro and Kakun areas in Nigeria

\begin{tabular}{|c|c|c|c|c|c|c|c|c|}
\hline \multirow[b]{2}{*}{ Oxides } & \multicolumn{2}{|c|}{ This Study } & \multicolumn{2}{|c|}{ Maru } & \multicolumn{2}{|c|}{ Muro } & \multicolumn{2}{|c|}{ Kakun } \\
\hline & Average & Range & Average & Range & Average & Range & Average & Range \\
\hline $\mathrm{SiO}_{2}$ & 41.98 & $34.36-48.26$ & 34.35 & $26.33-43.95$ & 57.66 & $51-64.96$ & 20.17 & $13.50-30.46$ \\
\hline $\mathrm{TiO}_{2}$ & 0.37 & $0.29-0.44$ & 0.16 & $0.01-0.29$ & 0.02 & $0.01-0.05$ & 1.74 & $1.45-1.98$ \\
\hline $\mathrm{Al}_{2} \mathrm{O}_{3}$ & 1.41 & $0.98-2.30$ & 4.25 & $2.25-9.19$ & 0.28 & $0.09-0.55$ & 8.12 & $8.00-8.40$ \\
\hline $\mathrm{Fe}_{2} \mathrm{O}_{3(\mathrm{t})}$ & 53.91 & $47.86-61.77$ & 54.30 & $45.16-60.55$ & 42.02 & $38.71-48.62$ & 56.80 & $50.55-61.75$ \\
\hline $\mathrm{MnO}$ & 0.09 & $0.08-0.10$ & 4.83 & $2.31-9.94$ & 0.06 & $0.03-0.12$ & 0.07 & $0.05-0.09$ \\
\hline $\mathrm{MgO}$ & 0.02 & $<0.01-0.03$ & 0.13 & $<0.01-0.44$ & 0.01 & $0.01-0.06$ & 3.58 & $2.01-4.42$ \\
\hline $\mathrm{CaO}$ & 0.05 & $0.04-0.06$ & 0.11 & $0.03-0.20$ & 0.02 & $0.01-0.10$ & 6.68 & $4.20-8.40$ \\
\hline $\mathrm{Na}_{2} \mathrm{O}$ & 0.18 & $0.05-0.32$ & 0.01 & $0.01-0.06$ & 0.01 & $0.01-0.01$ & 1.10 & $0.98-1.22$ \\
\hline $\mathrm{K}_{2} \mathrm{O}$ & 0.44 & $0.10-0.80$ & 0.65 & $0.01-3.01$ & 0.02 & $0.01-.0 .07$ & 0.77 & $0.50-0.93$ \\
\hline $\mathrm{P}_{2} \mathrm{O}_{5}$ & $<0.01$ & $<0.01$ & 0.09 & $0.04-0.20$ & 0.05 & $0.01-0.15$ & 0.27 & $0.16-0.60$ \\
\hline LOI & 1.47 & $0.90-1.90$ & 3.47 & $1.79-5.98$ & 0.81 & $0.01-2.14$ & ND & ND \\
\hline Total & 99.92 & & & & & & & \\
\hline \multicolumn{9}{|c|}{ Trace elements (ppm) } \\
\hline $\mathrm{Ba}$ & 198 & $67-332$ & 293 & $164-802$ & 41 & $<9-99$ & ND & ND \\
\hline $\mathrm{Co}$ & 31 & $22-45$ & 100 & $80-173$ & 166 & $142-194$ & 47 & $36-59$ \\
\hline $\mathrm{Cr}$ & 46 & $41-60$ & 23 & $<10-36$ & 10 & $<10-19$ & 100 & $86-114$ \\
\hline $\mathrm{Cu}$ & 15 & $10-25$ & $<10$ & $<10$ & 40 & $<10-264$ & 37 & $30-45$ \\
\hline $\mathrm{Nb}$ & 16 & $11-19$ & 5 & $<5-9$ & 5 & $<5-7$ & ND & ND \\
\hline $\mathrm{Ni}$ & 30 & $28-35$ & $<10$ & $<10$ & $<10$ & $<10$ & 116 & $75-181$ \\
\hline $\mathrm{Sc}$ & 4 & $3-4$ & ND & ND & ND & ND & ND & ND \\
\hline $\mathrm{Sr}$ & 36 & $13-55$ & 51 & $32-179$ & 18 & $16-20$ & ND & ND \\
\hline $\mathrm{Y}$ & 7 & $5-8$ & 22 & $9-45$ & $<5$ & $<5$ & ND & ND \\
\hline $\mathrm{Zn}$ & 12 & $10-15$ & 26 & $<10-90$ & $<10$ & $<10$ & 143 & $120-186$ \\
\hline $\mathrm{Zr}$ & 20 & $16-25$ & 60 & $50-85$ & 39 & $36-41$ & ND & ND \\
\hline
\end{tabular}

ND: Not determined or reported.

The Gangfelum BIF consists predominantly of oxide facies, which is represented by the silica-iron oxide assemblage similar to the Muro BIF, though the latter include minor carbonate facies of siderite and metachert (Adekoya et al. 2012). The Maru BIF, on the other hand, consists of magnetite-oxide facies with minor silicatebearing facies (Adekoya, 1998). The trace element concentration of the Gangfelum BIF is similarly low, which is characteristic of Precambrian iron formations (James, 1954, 1983). The nickel contents of Kakun ore (75-181 ppm) is considerably higher than those of the Gangfelum $(28-35 \mathrm{ppm})$, the Maru $(<10 \mathrm{ppm})$ and the Muro BIFs $(<10$ ppm). The Ganfelum BIF is similar to other Precambrian BIFs in other parts of the world (Table 3). The MnO 
(0.09 wt.\%) and most of the trace elements of the Gangfelum BIF is comparable to the Algoma oxide facies iron formation from North America, the Orissa iron oxide facies of India and the Itabirite from Minas Gerais, Brazil (Majumder et al., 1982).

\subsection{Origin of the Gangfelum BIF}

The Gangfelum BIF is located within the Precambrian basement complex of northeastern Nigeria which has not been studied in detail compared to other parts of Nigeria. Minor BIF-related metasediments, similar in parts to those obtained in adjacent Cameroon (Chombong et al., 2013) occur within the basement rocks, thus refuting the previous assumption that the Nigerian schist belts are restricted to the western half of the country.

The formation of the BIF began with the transition of clastic sedimentation to chemical sedimentation in a restricted or proto basin. Weathering, erosion and sedimentation was lithologically and stratigraphically controlled with paleogeographic and climatic implications. Several basalts, granitoids and gneisses provided the primary source of iron through weathering. The environment and climatic conditions were favourable for the liberation and concentration of iron in the soils during the weathering of the continental areas. It is therefore postulated that iron and silica were carried in solution from the nearby continental mass and were rhythmically deposited as sediments in water through direct precipitation. The chemically precipitated iron and silica were metamorphosed and recrystallized to hematite-quartz rocks. The banding of the BIF suggested a break in iron precipitation probably due to iron oxide deficiency.

Table 3. Averages and ranges of major oxide (wt.\%) and trace elements (ppm) of iron-formations from Gangfelum, Maru compared with the Lake Superior (USA), Algoma (Canada), Orissa (India) and Itabirite (Brazil) silicate and oxide facies iron formations

\begin{tabular}{|c|c|c|c|c|c|c|}
\hline \multirow[b]{2}{*}{ Oxides } & \multicolumn{2}{|c|}{ This Study } & \multirow{2}{*}{$\begin{array}{c}{ }^{1} \text { Lake } \\
\text { Superior }\end{array}$} & \multirow{2}{*}{$\begin{array}{l}{ }^{2} \text { Algoma } \\
\text { (Canada) }\end{array}$} & \multirow{2}{*}{$\begin{array}{l}{ }^{3} \text { Orissa } \\
\text { (India) }\end{array}$} & \multirow{2}{*}{$\begin{array}{l}{ }^{4} \text { Itabirite } \\
\text { (Brazil) }\end{array}$} \\
\hline & Average & Range & & & & \\
\hline $\mathrm{SiO}_{2}$ & 41.98 & $34.36-48.26$ & 47.20 & 50.50 & 49.13 & 51.58 \\
\hline $\mathrm{TiO}_{2}$ & 0.37 & $0.29-0.44$ & 0.21 & 0.02 & 0.02 & 0.09 \\
\hline $\mathrm{Al}_{2} \mathrm{O}_{3}$ & 1.41 & $0.98-2.30$ & 1.39 & 3.00 & 1.45 & 3.06 \\
\hline $\mathrm{Fe}_{2} \mathrm{O}_{3(\mathrm{t})}$ & 53.91 & $47.86-61.77$ & 35.4 & 26.90 & 46.33 & 42.62 \\
\hline $\mathrm{MnO}$ & 0.09 & $0.08-0.10$ & 0.73 & 0.06 & 0.76 & 0.14 \\
\hline $\mathrm{MgO}$ & 0.02 & $<0.01-0.03$ & 1.24 & 0.01 & 1.29 & 1.56 \\
\hline $\mathrm{CaO}$ & 0.05 & $0.04-0.06$ & 1.58 & 1.51 & 1.64 & 1.54 \\
\hline $\mathrm{Na}_{2} \mathrm{O}$ & 0.18 & $0.05-0.32$ & 0.12 & 0.31 & 0.12 & 0.32 \\
\hline $\mathrm{K}_{2} \mathrm{O}$ & 0.44 & $0.10-0.80$ & 0.14 & 0.58 & 0.15 & 0.59 \\
\hline $\mathrm{P}_{2} \mathrm{O}_{5}$ & $<0.01$ & $<0.01$ & 0.06 & 0.21 & 0.06 & 0.21 \\
\hline LOI & 1.47 & $0.90-1.90$ & ND & ND & ND & ND \\
\hline \multicolumn{7}{|c|}{ Trace elements (ppm) } \\
\hline $\mathrm{Ba}$ & 198 & $67-332$ & 180 & 170 & 70 & 179 \\
\hline $\mathrm{Co}$ & 31 & $22-45$ & 27 & 38 & 35 & 69 \\
\hline $\mathrm{Cr}$ & 46 & $41-60$ & 122 & 78 & 30 & 28.5 \\
\hline $\mathrm{Cu}$ & 15 & $10-25$ & 10 & 96 & 10 & 22 \\
\hline $\mathrm{Nb}$ & 16 & $11-19$ & ND & ND & ND & ND \\
\hline $\mathrm{Ni}$ & 30 & $28-35$ & 32 & 83 & 83 & 20.3 \\
\hline $\mathrm{Sc}$ & 4 & $3-4$ & ND & ND & ND & ND \\
\hline $\mathrm{Sr}$ & 36 & $13-55$ & 42 & 83 & 15 & 20.5 \\
\hline $\mathrm{Y}$ & 7 & $5-8$ & 41 & 54 & ND & ND \\
\hline $\mathrm{Zn}$ & 12 & $10-15$ & 2 & 33 & ND & ND \\
\hline $\mathrm{Zr}$ & 20 & $16-25$ & 56 & 84 & 10 & 17.3 \\
\hline
\end{tabular}

ND: Not determined or reported.

1 - Lake Superior silicate facies BIF, North America (Gross \& Mcleod, 1980; Suresh \& Basavanna, 2014; Selmiet al., 2009).

2 - Algoma oxide facies iron formation, North America (Gross and Mcleod, 1980).

3 - Orissa oxide faciesiron formation, India (Majumder et al., 1982).

4 - Itabirite from Mines Gerais, Brazil (Majumder et al., 1982). 


\section{Conclusions}

The Gangfelum iron formation is located within the basement complex of northeastern Nigeria, which consists mainly of migmatite-gneiss, biotite-hornblende gneiss and porphyritic granites. The average $\mathrm{Fe}_{2} \mathrm{O}_{3(\mathrm{t})}$ content is high (53.91 wt.\%) while $\mathrm{TiO}_{2}, \mathrm{Al}_{2} \mathrm{O}_{3}, \mathrm{MgO}, \mathrm{CaO}, \mathrm{Na}_{2} \mathrm{O}, \mathrm{K}_{2} \mathrm{O}, \mathrm{MnO}$ and $\mathrm{P}_{2} \mathrm{O}_{5}$ are low. The trace element concentrations are low and similar to other Precambrian BIFs in the world. The iron ore consists predominantly of the oxide facies. Geological evidences support a metasedimentary origin. The iron and silica were chemically precipitated, metamorphosed and recrystallized to hematite-quartz rocks. The banding of the BIF suggested a break in precipitation of iron probably due to iron oxide deficiency.

\section{Acknowledgements}

The author thanks Mr. Saleh I. Bute for the field assistance, Miss. Chiamaka Ekwueme for the preparation of diagrams and the anonymous reviewers for their extremely useful suggestions.

\section{References}

Abhulimen, G. A. (1986). A preliminary structure and magnetic mapping of an iron ore occurrence near Kakun, Kabba, Nigeria. Unpublished M.Sc. Dissertation, University of Ilorin, Ilorin, Nigeria.

Adekoya, J. A. (1998). The geology and geochemistry of the Maru Banded Iron-Formation, northwestern Nigeria. Journal of African Earth Sciences, 27(2), 241-257.

Adekoya, J. A., Okonkwo, C. T., \& Adepoju, M. O. (2012). Geochemistry of Muro Banded Iron-Formation, Central Nigeria. International Journal of Geosciences, 3, 1074-1083.

Bhattacharya, H. N., Chakraborty, I., \& Ghosh, K. K. (2007). Geochemistry of some Banded Iron Formations of the Archean supracrustals, Jharkhand-Orissa Region, India. Journal of Earth System Science, 116(3), 245259.

Chombong, N. N., Suh, C. E., \& Ilouga, C. D. C. (2013). New detrital zircon U-Pb ages from BIF-related metasediments in the Ntem Complex (Congo craton) of southern Cameroon, West Africa. Natural Science, $5(7), 835-847$.

Fitton, G. (1980). The Benue Trough and Cameroun line: a migrating rift system in West Africa. Earth Planetary Science Letters, 7(5/6), 132-138, 1980.

Govett, G. J. S. (1966). Origin of banded iron-formation. Geological Society of Ameria Bulletin, 77, 1191-1212.

Gross, G. A., \& Mcleod, C. R. (1980). A preliminary assessment of the chemical composition of iron formations in Canada. Canadian Mineralogists, 18, 223-230.

Haruna, I. V., Orazulike, D. M., \& Ofulume, A. B. (2011). Preliminary geological and radiometric studies of granitoids of Zing-Monkin area, Adamawa Massifs, NE Nigeria. Global Journal of Geological Sciences, 9(2), 123-134.

Haruna, I. V., Orazulike, D. M., \& Samalia, N. K. (2013). Trace and rare-earth elements geochemistry petrochemical constraint on tectogenetic evolution of the granitoids of Zing-Monkin area, Adamawa Massif, Northeastern Nigeria. Research Journal of Chemical Sciences, 3(1), 32-42.

James, H. L. (1954). Sedimentary facies of iron-formations. Economic Geology, 49, 235-293.

James, H. L. (1983). Distribution of Banded Iron Formation in space and time. In Trendall, A. F., \& Morris, R. C. (Eds.), Iron-formation: Facts and Problems (Eds) (Amsterdam: Elsevier), 471-490.

JCPDS. (1974). Selected Powder Diffraction Data for Minerals. 1st edition, (Ed. L.G. Berry), Joint Committee on Powder Diffraction Standards, Philadelphia, 833p.

Majumder, T., Chakraborty, K. L., \& Bhattacharjee, A. (1982). Geochemistry of Banded Iron Formation of Orissa, India. Mineralium Deposita, 17, 107-118.

Mucke, A., \& Neumann, U. (1986). The genesis of the banded iron ore deposits of Itakpe area, Kwara State, Nigeria. Fortachritte der Mineralogie, 64, 187-204.

Okolo, E. C. (1987). Mineralogical and chemical studies of the Iron ore body associated with the Precambrian basement rocks in Kakun District, southwestern Nigeria. Unpublished M.Sc. Dissertation, University of Ibadan, Ibadan, Ibadan, 101p.

Okonkwo, C. T. (1980). The geochemistry and mineralogy of the Kushaka Banded Iron Formation and associated rocks. (Unpublished M.Sc. Dissertation), University of Ibadan, Ibadan, Nigeria, 113. 
Olade, M. A. (1978). General features of Precambrian iron ore deposits and its environment at Itakpe, Okene, Nigeria. Transactions of Institute of Mining and Metallurgy, London, Section B. Applied Earth Science, 87, 81-89.

Oyawoye, M. O. (1970). The Basement Complex of Nigeria. In Dessauvagie, T. F. J., \& Whiteman, A. J. (Eds), African Geology (pp. 67-99). University of Ibadan press.

Selmi. M., Lagoeiro, L. E., \& Endo, I. (2009). Geochemistry of Hematite and Itabirite, Quadrilátero Ferrífero, Brazil. REM - Revista Escola de Minas, 62(1), 35-43.

Suresh, S. R., \& Basavanna, M. (2014). Geology and Geochemistry of Banded Iron Formations from Joga (Sandur Schist Belt) and associated gold mineralisation. International Journal of Earth Sciences and Engineering, $7(2), 382-392$.

\section{Copyrights}

Copyright for this article is retained by the author(s), with first publication rights granted to the journal.

This is an open-access article distributed under the terms and conditions of the Creative Commons Attribution license (http://creativecommons.org/licenses/by/4.0/). 